\title{
Supporting Activities for Critical Thinking Skills Development Based on Students' Perspective
}

\author{
Bambang Eko Susilo ${ }^{1,2}$, Darhim ${ }^{1}$, Sufyani Prabawanto ${ }^{1}$ \\ \{bambangekosusilo@student.upi.edu,darhim@upi.edu, sufyani@upi.edu\} \\ Universitas Pendidikan Indonesia, Bandung 40154, West Java, Indonesia \\ Universitas Negeri Semarang, Semarang 50229, Central Java, Indonesia ${ }^{2}$
}

\begin{abstract}
Development of critical thinking skills requires learning strategies that encourage students to carry out supporting activities for critical thinking skills development. This study aims to find out the various types of supporting activities for critical thinking skills development based on students' perspective. This study used an exploratory survey method. Data was taken with an open questionnaire from 58 students of the mathematics department at a university in Central Java. The results show that supporting activities for critical thinking skills development based on students' perspective in a row from the most supportive are discussion (37.10\%), question and answer (22.58\%), get an explanation or motivation $(14.51 \%)$, try or solve problems $(9.68 \%)$, presentation $(8.06 \%)$, work on project tasks $(4.84 \%)$, and solve HOTS problems or problems related to everyday life $(3.23 \%)$.
\end{abstract}

Keywords: Supporting activities, Critical thinking, Development, Students' perspective.

\section{Introduction}

Critical thinking skills are an important aspect that should be developed in mathematics learning. The importance of critical thinking skills has been a concern of the government to include them in mathematics learning objectives in each curriculum development. In addition to critical thinking skills, other mathematical abilities that are included in learning objectives are the ability of logical, rational, creative, systematic, and practical thinking. Critical thinking is one of the family members of higher order thinking skills (HOTS) that closely related to one another, such as problem-solving, decision making, and creative thinking [1]. Critical thinking skills as one of HOTS is required to solve problems in mathematics as well as in a complex matter, in the life of multinational and multicultural relations in the era of industrial revolution 4.0. Society must be able to filter large amounts of data to make intelligent decisions, so that critical thinking skills are important skills to be owned by all members of society [2]-[6]. Critical and creative thinking are interrelated with each other in producing effective thinking and problem-solving [7]-[9]. In general, critical thinking has benefits in (1) solving problems, (2) helping to consider decision making, (3) distinguishing between facts and opinions, and (4) presenting calm in facing difficult problems.

Critical thinking had been defined by some experts. Critical thinking can be defined as reflective and reasonable thinking to decide what is believed or done [10]. Critical thinking is also defined as thinking skillfully and responsibly with good judgment because it is based on (a) criteria, (b) self-correction, and (c) context-sensitive [11]. In addition, critical thinking is 
also defined as a propensity and skill with reflective skepticism in some specific activity [12]. Critical thinking is also interpreted as a purposeful and self-regulating judgment that results in interpretation, analysis, evaluation, inference and explanation of the considerations in the form of evidences, concepts, methods, or criteria upon which judgment is based [1]. Critical thinking can also be interpreted as disciplined and self-directed thinking which exemplifies the perfection of thinking according to a particular mode or domain of thought [13]. In addition to these definitions, critical thinking can also be interpreted as thinking with a particular quality that is essentially good thinking and meets specified criteria or standards of adequacy and accuracy [14].

The effort to develop critical thinking skills is certainly through a process that is not short. Critical thinking skills need to be prepared as one of learning and innovation skills of students to take post-secondary school and also as labor [15]. The development of critical thinking skills to support problem-solving abilities should begin from primary education to higher education. Thus the problems of mathematical problem solving should have been given at primary education, secondary education, up to higher education tailored to the student's character.

The development of critical thinking skills requires active efforts from teachers or lecturer as educators so that it can develop well on students. In developing the critical thinking skills in mathematics learning, the role of a teacher or lecturer is very important. This role is realized by providing learning and complete facilities that support efforts to realize aspects of students' critical thinking skills, among others by providing or selecting curriculum materials, media, and mathematics learning strategies that facilitate the development of aspects of students' critical thinking skills [16], [17].

The preparation of mathematics learning strategies is realized in the preparation of lesson plans to be implemented in classroom learning. The preparation of mathematics learning strategies is strived by selecting learning scenarios that can bring up supporting activities for critical thinking skills development. Supporting activities for critical thinking skills development can be viewed from a variety of perspectives, including from student perspective, teacher perspective, expert perspective or other stakeholder perspectives. Learning activities will be run well and effectively if the learning strategies that selected by the teacher or lecturer in accordance with the needs and conditions of students to learn and accordance too with the learning objectives to be achieved.

Paul B. Diedrich has classified student activities into eight types of activities, namely as follows: (a) visual activities, such as: reading, paying attention to demonstration images; (b) oral activities, such as: stating, asking, giving advice, issuing opinions, discussing; (c) listening activities, for example listening; (d) writing activities, such as: writing, copying; (e) drawing activities, for example drawing; (f) motor activities, for example playing music; (g) mental activities, such as: responding to and understanding the subject matter; and (h) emotional activities, such as: interest, feeling bored, happy, excited [18].

This paper discusses the results of a study that aims to find out the various types of supporting activities for critical thinking skills development based on students' perspective.

\section{Method}

This research used a survey method with explorative type. The research population was students of the mathematics department at a university in Central Java in the 2016/2017 academic year, with a sample of 58 students. The instrument used was a questionnaire with open 
questions. Questions were prepared to find out the various types of supporting activities for critical thinking skills development based on students' perspective.

The respondents were given opportunities freely to answer questions about various types of supporting activities for critical thinking skills development from the lectures they attended so that one student might answer more than one type of activity. The questions were: "of all your activities, in the lectures that you follow, which activities do you think can develop your critical thinking skills?".

\section{Results and Discussion}

Data from the result of filling out the questionnaire by the respondents about various supporting activities for critical thinking skills development based on students' perspective can be seen in Table 1. Based on Table 1, it can be seen that supporting activities for critical thinking skills development based on students' perspective in a row from the most supportive are discussion (37.10\%), question and answer (22.58\%), get an explanation or motivation (14.51\%), try or solve problems $(9.68 \%)$, presentation $(8.06 \%)$, work on project tasks $(4.84 \%)$, and solve HOTS problems or problems related to everyday life (3.23\%).

Table 1. Supporting Activities for Critical Thinking Skills Development Based on Students' Perspective

\begin{tabular}{ll}
\hline Supporting Activities for Critical Thinking Skills Development & Percentage \\
\hline Discussion & 37.10 \\
Question and answer & 22.58 \\
Get an explanation or motivation & 14.51 \\
Try or solve problems & 9.68 \\
Presentation & 8.06 \\
Work on project tasks & 4.84 \\
Solve HOTS problems or problems related to everyday life & 3.23 \\
\hline
\end{tabular}

Based on Table 1, it can be seen that students have done most of the learning activities from 8 types of activities classified by Paul B. Diedrich both physical and mental activities. The data in Table 1 with the percentage of degraded is evidence that students are more interested in getting a learning strategy with activities that have a greater percentage. But the activities data then do not become a necessity for the lecturer to facilitate all of the activities in the learning strategy, because a lecturer has a prerogative policy to determine the learning objectives. Learning activities data in Table 1 are learning activities that students like will be an interesting reference for creating learning scenarios so that students feel comfortable.

Specifically, in Table 1, the students mentioned that activities to solve HOTS problems or problems related to daily life can support the development of critical thinking skills but with a small percentage of only $3.23 \%$. This is natural because only students with high motivation were interested in solving problems of problem-solving such as HOTS or problems related to everyday life. So that this data becomes an evaluation and reflection for the lecturers to be able to provide motivation to students so that their motivation increases.

In developing learning strategies that support the development of students' critical thinking skills, lecturer activities must adjust to the objectives, materials and learning media to manage the class. Lecturer selects learning scenarios by providing a set of questions and/or commands 
that facilitate students to carry out activities that support aspects of their critical thinking skills. Learning strategies that can be chosen are as follows: using paired discussion methods, cooperative active learning, as well as giving questions and/or commands such as (1) asking for further explanation or other opinions from an explanation/opinion of a student, (2) asking students to give reasons, evidence, implication or ultimate goal, (3) asking students to provide various alternative solutions of problems, and (4) if the explanation/opinion/answer is not correct, students are asked to evaluate or trace errors or forgotten things [19], [20]. The next strategy is to compile an assessment instrument that supports the emergence of aspects of critical thinking skills with incomplete (ill-structure) problems or asked to develop problems that arise in addition to those owned.

Efforts or strategies in realizing aspects of critical thinking skills in learning mathematics as explained above must eventually be prepared by lecturers both in the stages of planning, implementing and evaluating learning. The efforts of implementation learning become very important because of direct contact with students. Learning strategies efforts are manifested in the form of instructions or questions that can facilitate students' critical thinking skills. So that the ability of lecturers to manage classes and provide questions must be considered.

The learning strategy selection for students in classical, groups, pairs or individuals should be adjusted to the conditions and background of students. While the questions or mathematical problems that are given are selected and adapted to the curriculum.

\section{Conclusion}

The Development of critical thinking skills requires learning strategies that encourage students to carry out supporting activities for critical thinking skills development. Supporting activities for critical thinking skills development based on students' perspective in a row from the most supportive are discussion $(37.10 \%)$, question and answer $(22.58 \%)$, get an explanation or motivation $(14.51 \%)$, try or solve problems $(9.68 \%)$, presentation $(8.06 \%)$, work on project tasks $(4.84 \%)$, and solve HOTS problems or problems related to everyday life $(3.23 \%)$. These data are expected to become an evaluation and reflection for the lecturers to be able to provide motivation to students so that their motivation increases.

\section{References}

[1] Facione, P. A.: Critical thinking: A statement of expert consensus for purposes of educational assessment and instruction. The Delphi Report, pp. 1-19. California Academic Press, California (1990)

[2] Aizikovitsh-Udi, E., Miriam, A.: Developing the skills of critical and creative thinking by probability teaching. Procedia Social and Behavioral Sciences. Vol. 15, pp.1087-1091 (2011)

[3] Colley, B. M., Bilics, A. R., Lerch, C. M.: Reflection: A key component to thinking critically. The Canadian Journal for the Scholarship of Teaching and Learning, Vol. 3(1), pp. 1-19 (2012)

[4] Kalelioglu, F., Gulbahar, Y.: The effect of instructional techniques on critical thinking and critical thinking disposition in online discussion. Education Technology \&amp; Society, Vol.17(1), pp. 248258, (2014)

[5] Kriel, C.: Creating a disposition for critical thinking in the mathematics classroom. Proceedings of the Second Biennial Conference of the South African Society for Engineering Education, Cape Town (2013)

[6] Aizikovitsh-Udi, E., Cheng, D.: Developing critical thinking skills from disposition to abilities: mathematics education from early childhood to high school. Creative Education, Vol. 6, pp. 455- 
462, (2015)

[7] Bailin, S.: Critical and creative thinking. Informal Logic, Vol. 9(1), pp. 23-30, (1987)

[8] Treffinger, D. J., Isaksen, S. G., Stead-Dorval, B. K.: Creative problem solving: an introduction. Prufrock Press, Waco, TX (2006)

[9] Masek, A., Yamin, S.: The effect of problem based learning on critical thinking ability: a theoretical and empirical review. International Review of Social Sciences and Humanities, Vol. 2(1), pp. 215 $221,(2011)$

[10] Ennis, R. H.: A logical basis for measuring critical thinking skills. Educational Leadership, Vol. 43(2), pp. 44-48, (1985)

[11] Lipman, M.: Critical thinking-What can it be? Educational Leadership, Vol. 46(1), pp. 38-43, (1988)

[12] McPeck, J. E.: Critical thinking and subject specificity: A reply to Ennis. Educational Researcher, Vol. 19(4), pp. 10-12, (1990)

[13] Paul, R. W.: Critical thinking: What, why, and how. New Directions for Community Colleges, Vol. 77, pp. 3-24. (1992)

[14] Bailin, S.: Critical thinking and science education. Science \&amp; Education, Vol. 11(4), pp. 361$375,(2002)$

[15] Lai, E. R.: Critical thinking: a literature review. Research Report, Pearson, (2011)

[16] Rifqiyana, L., Masrukan, Susilo, B. E.: Analisis kemampuan berpikir kritis siswa kelas VIII dengan pembelajaran model $4 \mathrm{~K}$ ditinjau dari gaya kognitif siswa. Unnes Journal of Mathematics Education, Vol. 5(1), pp. 40-46, (2016)

[17] Widodo, S. A., Darhim, Ikhwanudin, T.: Improving mathematical problem solving skills through visual media. Journal of Physics: Conference Series, Vol. 948(1), pp. 1-7, (2018)

[18] Sardiman, A. M.: Interaksi dan motivasi belajar mengajar. Rajawali Press, Jakarta (2011)

[19] King, A.: Designing the instructional process to enhance critical thinking across the curriculum. Teaching of Psychology, Vol. 22(1), pp. 13-17, (1995)

[20] Zhao, C., Pandian, A., Singh, M. K. M.: Instructional strategies for developing critical thinking in EFL classrooms. English Language Teaching; Vol. 9(10), pp. 14-21, (2016) 